\title{
Coding in Classic Grounded Theory: I've Done an Interview; Now What?
}

\author{
Barry Chametzky1,2,3 \\ ${ }^{1}$ Washington \& Jefferson College, Washington, PA, USA \\ ${ }^{2}$ Ozarks Technical Community College, Springfield, MO, USA \\ ${ }^{3}$ City University of Seattle, Seattle, WA, USA \\ Email: barry@bluevine.net
}

How to cite this paper: Chametzky, B. (2016). Coding in Classic Grounded Theory: I've Done an Interview; Now What? Sociology Mind, 6, 163-172.

http://dx.doi.org/10.4236/sm.2016.64014

Received: August 23, 2016

Accepted: September 19, 2016

Published: September 22, 2016

Copyright (๑) 2016 by author and Scientific Research Publishing Inc. This work is licensed under the Creative Commons Attribution International License (CC BY 4.0).

http://creativecommons.org/licenses/by/4.0/

\begin{abstract}
Without a doubt, many graduate students-especially those who do not have a mentor skilled in the classic grounded theory design-are concerned about doing studies or dissertations using the classic grounded theory design for fear of doing them incorrectly. While there is extant literature in the field of classic grounded theory, a clear and simple how-to does not exist. The purpose of this paper is to give novice researchers interested in the classic grounded theory design a foothold in how to do one aspect of classic grounded theory analysis: coding. The explanation offered in this paper is based in theory and supported with practical examples.
\end{abstract}

\section{Keywords}

Classic Grounded Theory, Coding

\section{Introduction}

Congratulations on conducting your first interview for your dissertation using classic grounded theory. Now the fun and, no doubt, the confusion truly begin. As you know, several theorists (Glaser, 1978; Mezirow, 1978) spoke about the educational power and importance of confusion. Now it is the time when you get to experience this "epistemological anarchy" (Glaser, 2005: p. 43). Despite what Glaser (1998) said, classic grounded theory is complicated for novice researchers. Yet, in order to ease possible frustrations, I will discuss what codes are and are not, different types of codes, and the overall process coding from a theoretical and practical perspective. In this manner, the reader will be able to see how theory and practice come together.

\section{Significance of This Research}

Without a doubt, many graduate (masters and doctoral) students-especially those who 
do not have a mentor skilled in the classic grounded theory design (Glaser, 1998) - are concerned about doing studies or dissertations using the classic grounded theory design for fear of doing them incorrectly. While there is extant literature in the field of classic grounded theory, a clear and simple how-to does not exist. Because the process of acculturation, so to speak, into the classic grounded theory realm takes time and requires novice researchers to ask numerous questions, this paper will be extremely valuable to them as it allows any minus mentored (Glaser, 1998) researcher to understand the research design more easily. Tangentially, this research will help allay some fears of novice researchers; with lowered fears and lowered affective filters (Chametzky, 2014), these researchers would be able to conduct their research more expeditiously.

\section{What Is Classic Grounded Theory?}

According to one of the founders of classic grounded theory, Glaser (2009), this research design is a "simple procedural method formulated to generate substantive, conceptual theory" (p. 72). While no person would ever doubt Glaser, it might be more useful to novice researchers to elaborate on (and clarify) what he said. Grounded theory is a research design in which a researcher explains the behaviors of participants vis-à-vis their main concern. The explanation, derived solely and exclusively from the (qualitative or quantitative) data, takes the ultimate form of a theory that explains the behaviors. While the theory may be unique to the particular group of people, called the substantive area, because the concepts are abstract of "time, place, and people" (Glaser, 2001: p. 10), a highly developed, conceptualized theory is created.

The term "classic" comes from the fact that Glaser and Strauss (1967) were the first two theorists to develop this research design. Subsequent to Glaser and Strauss in 1967, numerous other researchers have developed what they described as other types of grounded theory designs. In this paper, however, the researcher is discussing solely the (pure) classic grounded theory design.

\section{What Are Codes?}

Let us begin this discussion with what codes are from a practical perspective. Codes are one- or two-word ideas that cogently and succinctly explain what is happening in the data. They are the mechanism that allows you get from raw data to a well-developed theory (Holton, 2010). In other words, a code is how you, the researcher, conceptualize the data (Glaser, 1992). Additionally, codes are gerunds-verbs that end in -ing. Some examples of codes could be limiting, minimizing, feeling fearful, and so on. As you start your coding, if you need or want to create a made-up word (like fearfulizing [sic], to use an example from the previous sentence), to describe the various slices or segments of (raw) data, do so. In time, you will capture "the data in a [more] mature way" (Glaser, 1978: p. 61).

Conceptualization versus description. Codes are conceptual in order to achieve maximum generalizability; they are "concepts are abstract of time, place and people and that concepts have enduring grab, which appeal can literally go on forever as an applied 
way of seeing events" (Glaser, 2001: p. 10). With conceptualization, the what-is-happening-in-the-data-ness becomes generalizable and modifiable to other places, times, and people. Description, on the other hand, limits the ideas to specific situations.

This theoretical explanation is important so that the reader could appreciate a more practical perspective: Imagine you had raw data that you could explain in one of two ways: either 1) reducing teaching duties or 2) limiting. Which idea is more descriptive and which seems not to be tied to a specific time, place, or person (Glaser, 2001)? Does it not seem that the idea of reducing teaching duties explains a specific situation while limiting is broader? In the case of codes, broadness is desirable. In the theory of surviving situational suffering (Chametzky, 2015), though the substantive area is part-time adjunct instructors in the United States, the idea of overcoming obstacles in order to make it through each day is common to many different walks of life. Thus, while the idea of reducing teaching duties was an important concept in the theory, I needed to ask myself, through memos, what that idea meant. The idea of reducing teaching duties, vis-à-vis the aforementioned theory, referred to how adjunct educators were limited.

Conceptualizing codes initially-especially for novice researchers in classic grounded theory-is challenging. With this idea in mind, consider simply explaining what is going on in the data even if you use a descriptive idea. Additionally, as you look at your interview data and start to code it, if you create a code that is neither a gerund nor a gerund-phrase, put it down. Or, if you have more than one gerund to explain the slice of data, put them down. Don't be concerned at this point that you feel you didn't code correctly. As you constantly compare the codes, and ask yourself what is going on in the data, and what the main concern is of the participants, you will tweak your codes in

order to "capture the data in a mature way" (Glaser, 1978: p. 61). Thus, if you need to describe initially, do it; code conceptualization will come in time.

\section{The Coding Process}

Now that we have spoken about codes, let us look at sample interview data and see how to code it in an efficient manner. The process from doing an interview to coding, writing memos, and ultimately developing a theory is sometimes challenging, as novice researchers do not know how to advance through the process. Though perhaps intimidating, the process is not as complex as first imagined.

Some practical suggestions during the initial (open) coding process. No doubt you have read Glaser (1978) who said that coding is done line-by-line. While that information is accurate, the important question to ask is how long is a line? There is a clear importance when you consider that a line could be, for example, 10 inches or 4 inches long; and, depending on the length of a line, there could be one or more than one code used to explain what is going on in the data. What would be better than doing a line-by-line analysis where each line might be 10 inches long would be to fracture the notes into shorter lines. In this way, each line could possibly have one idea. Additionally, with shorter lines, you will be in a better position to have the codes next to the data 
for easier analysis. This ease will be invaluable to you when you need to review your raw data as you selectively code.

When I was a doctoral student and candidate learning about classic grounded theory, one of the practice coding sessions we had in our online Skype cohort was extremely valuable. I reproduced part of that experience here and would like to give special thanks for Dr. Barbara Yalof, my coding buddy, for her gracious permission to share her codes on this exercise. The grand tour question (Spradley, 1979) in the following text was to talk about an "aha" moment. During the short (mock) interview initially done in written format, we were told to have the interview/raw data on the left-hand side of the paper and the associated codes on the right. By having the codes easily associated with the data, you would be in a better position to code the segments or incidents (Gibson \& Hartman, 2014). Additionally, if you write the code in a different color of ink on the same line as the text (see the Figure 1), then, if you need to go back to the raw data (if and when you feel you need to double-check yourself), you will be able to see the associated code immediately.

Glaser (1978) supported this format when he stated that researchers should "code in the margin right next to the indicator" (p. 71). If writing the (interview) data on shorter lines is not possible, then analyze "sentence by sentence" (Glaser, 1978: p. 16) rather

\begin{tabular}{|c|c|}
\hline Interview data & Codes \\
\hline $\begin{array}{l}\text { I'd have to say that an "aha" moment for me was the time I } \\
\text { spoke with a mentor at my school and asked for advice on a } \\
\text { particular topic. }\end{array}$ & $\begin{array}{l}\text { Being unsure and reaching out } \\
\text { Testing one's viewpoint }\end{array}$ \\
\hline $\begin{array}{l}\text { She suggested what I should do and I was amazed that I had } \\
\text { already done exactly what she wanted! }\end{array}$ & $\begin{array}{l}\text { Opening to suggestions and evaluating } \\
\text { alternatives }\end{array}$ \\
\hline $\begin{array}{l}\text { I should mention that I got to that point because of lots of } \\
\text { struggles and um what's the word... }\end{array}$ & Self-reflecting \\
\hline $\begin{array}{l}\text { bypass (not the right word). } \\
\text { OK ... I was struggling with GT and the dichotomy between } \\
\text { what Glaser/Strauss want/require and what my school } \\
\text { requires. I had done a lot of reading in various related (or } \\
\text { not so related) methodological/design areas and was } \\
\text { increasingly frustrated. }\end{array}$ & $\begin{array}{l}\text { Struggling to find a path } \\
\text { Feeling frustration }\end{array}$ \\
\hline $\begin{array}{l}\text { I decided that I was going to wear } 2 \text { hats: one what the } \\
\text { school wanted for the dissertation and one for GT. }\end{array}$ & $\begin{array}{l}\text { Developing a plan } \\
\text { Remaining optimistic }\end{array}$ \\
\hline $\begin{array}{l}\text { Well, that was the advice given to me. It was an "aha" } \\
\text { moment because I realized how contrary GT is to the } \\
\text { school's requirements. }\end{array}$ & $\begin{array}{l}\text { Determining a plan } \\
\text { Confronting unrealistic expectation }\end{array}$ \\
\hline $\begin{array}{l}\text { And it was also an "aha" moment because I was able to } \\
\text { figure out what to do by myself (only asking for help } \\
\text { afterwards). }\end{array}$ & Overcoming obstacles \\
\hline $\begin{array}{l}\text { Yes, I thought about (reflected) how in order to get the } \\
\text { degree, I have to do what the faculty, committees, etc. want } \\
\text { even if it goes against classical theory. }\end{array}$ & Reasoning out the plan \\
\hline $\begin{array}{l}\text { A related "aha" moment happened when I was told what } \\
\text { some of the seminal works in GT are. }\end{array}$ & Seeking information \\
\hline $\begin{array}{l}\text { Not only was I able to respectfully disagree with that } \\
\text { information but was able to explain why I disagreed. That } \\
\text { moment, too, showed me that I was definitely on the right } \\
\text { track! }\end{array}$ & $\begin{array}{l}\text { Raising self esteem } \\
\text { Experiencing self-efficacy }\end{array}$ \\
\hline
\end{tabular}

Figure 1. Sample coding format. 
than line-by-line. On the other hand, if you have a line of data that goes across the page, you could be in the situation where line-by-line coding might not work well as there could be several codes per line.

When I did my dissertation and took detailed notes during the phone or Skype sessions, I used half-sheets of paper for my raw data. It was a great use of scrap paper for me! On these sheets on which I wrote my interview notes/comments, on the right-hand side, in red ink (or at least a different color ink from the interview notes), I wrote my "ideas". I should explain that I put "ideas" in quotation marks because sometimes I did not use gerunds as I did not have the correct word at that moment to explain the data slice. Sometimes, too, I used made-up words like "alone-ing" to explain the data. I knew, too, that I was able to go back to my interviews and find a better, more appropriate word; memoing would help manifest any preconscious connections or words about which I didn't initially think.

In examining the aforementioned sample interview, here are some suggestions to keep in mind as you do your own research. First, as you notice, if you create two codes for the same slice of data, it is acceptable. Through comparing codes during the memo-writing phase, you will develop new, more exacting codes for the data you received. I will briefly discuss memos shortly.

Second, during this phase, called open coding because you code everything (Glaser, 1998), you need continually to ask yourself: What is the main concern of the participant? "What is this data a study of" (Glaser, 1978: p. 57)? And, what is actually happening in the data (Glaser, 1978: p. 57)? To not ask these questions will result in potentially misinterpreting the data and cause you to lose several hours of work. Remember that what participants say reflects directly their behaviors. When I did my dissertation, I neglected to keep the main concerns of participants in mind; the result was misdirected coding that required me to revisit the raw data and code anew.

Third, do your own coding by hand. Do not use a qualitative analysis tool (like NVivo) to help with your coding. The problem with software tools like NVivo is that they do not have the finesse that you do-even at this early stage in your grounded theory careers!

Finally, a corollary rule to not using qualitative tools to do your coding analysis would be to trust yourself and trust the grounded theory process. Many novice doctoral researchers using the classic grounded theory design want it to be done perfectly. I know I did when I did my dissertation. There is nothing wrong with wanting the methodology to be done perfectly. The problem, though, is that there might not be a definitive answer to "Am I doing this right?". It is important to trust yourself and know that you've carefully read the seminal classic grounded theory books and know the process. Now, you need to trust the grounded theory process because it really does work!

\section{Organizing Codes}

You will, certainly have a great deal of codes from your first interview. When I conducted my first classic grounded theory study, I had approximately 20 - 30 codes. As Glaser (1978) stated, in the beginning, "codes come very fast, and it is important to 
realize that these codes need correction by trimming and fitting" (pp. 60-61). During my coding process, I also looked for any important words that participants used. These in vivo terms were important as they added a level of richness since they expressed participants' "notions, behaviors, gestures, perspectives, attitudes, and so forth" (Stern \& Porr, 2011: p. 64).

When you finish coding your first interview, copy all the codes to a blank MS Word document. Be sure, of course, to omit duplicate codes. Have each code separated by a few blank lines. It is in this document, too, that you will start your memo writing. The nice thing about having all the code in one file is that when you start memoing and start constantly comparing and moving memos around, it will all be in one place. If you find you have similar codes, determine, through memoing, whether they are truly different or not. For example, in my study on offsetting the affective filter (Chametzky, 2013a), I found I had codes like isolating, causing aloneness, and alone-ing [sic]. By the way, do not be afraid to keep writing memos! I had approximately 70 pages of single-spaced memos when I wrote my dissertation. You will always have time to cut down the memos.

\section{Comparing Codes}

Now comes the excitement of comparing the codes with each other and trying to understand how one relates to another. As you compare and write memos, you will see patterns develop. Be sure to ask yourself continually, what is going on in the data (Glaser, 1978)? It is only through constantly comparing "incident to incident, incident to concept" (Glaser, 1992: p. 39) and, concept to concept (Glaser, 1978: p. 50) that a theory could be discovered. Additionally, it is through constant comparison that data become saturated so that categories and multivariate properties develop. Keep in mind, too, what the main concern is of the participants.

Comparing concepts is not necessarily challenging. The key is to ask how the terms are or might be related to one another and then write memos on that possible relationship. Remember that it is through memos that precious thought manifests itself (Chametzky, 2013b; Glaser, 1998). According to Glaser (1978), "Comparing the apparently non-comparable increases the broad range of groups and ideas available to the emerging theory" (p. 42). My favorite comparison is the one that Glaser (1978) made: "diarrhea and perfume both indicate body pollution" (p. 43).

At this point in your coding, no doubt you will have many codes and many more pages of memos; the aforementioned MS Word will become long. It might be challenging to scroll through many pages of memos to get to a code. As I started finding patterns (as manifested by possible categories and properties), I used a huge white board to write what I thought at that time were categories, their properties, and relationships. The white board was also useful as I was able to draw arrows and think aloud. Then, as possible connections were made, I wrote memos.

With the white board, I was able to see and draw possible connections. And, when a connection did not "feel" right, I learned the sensation was the direct result of forc- 
ing-or trying inadvertently to force-the data. I tried to fit what I thought were patterns into categories where they did not fit. I tried to fit data in places into which it would not go. Such an experience is normal and indicates that more analysis is needed. When you find what you think is your core variable with its properties, the data will indeed fit like a glove.

A word or two about memos. Though a detailed discussion about memos would be outside the realm of this document, it is nonetheless valuable briefly to discuss memos vis-à-vis coding. While many researchers (Chametzky, 2013b; Glaser \& Strauss, 1967; Glaser, 1978, 1992, 1998; Stern \& Porr, 2011) have discussed memos in classic grounded theory in great detail, novice researchers still have questions about what memos are. Memos are simply the written-down connections between incidents, codes, properties, and categories. As you write down your ideas about possible connections, you make apparent any unconscious connections (Chametzky, 2013b). Additionally, memos could be as long or as short as necessary-from one sentence to several pages.

To give the reader an example, let us imagine that we have a code of feeling stressed. A researcher could pose several questions to him-or herself to aid in writing the memo: What causes a feeling of stress? When and why does stress occur? How does stress manifest itself? Then, if the researcher has a second code of, say, behaving bizarrely, the researcher would need to compare the two codes and see how they are related and how they differ from one another. Connections will undoubtedly be established.

\section{Selective Coding}

As you develop categories, your core variable will undoubtedly emerge. During this phase of your analysis, you delimit and focus on the recurring issue (Stern \& Porr, 2011) and "related categories" (Glaser, 1998: p. 138). In other words, you no longer code everything in your data; you code selectively for the core variable in order to enrich your core variable and its properties. From a practical perspective, though, there is no difference between open and selective coding: you are still comparing ideas, incidences, and codes with one another; then you are writing memos. The difference now is that you are focusing on the categories and properties of your core variable.

If you find that your categories are not yet sufficiently multivariate, go back to your raw data (interview, field notes, etc.) and code in a more selective manner. It is acceptable, and indeed necessary, to re-examine your raw data several times during your analysis; each time you study it, you do so with a different objective and with a different eye. What you might have overlooked initially will become apparent now.

\section{Conceptualization and Theoretical Codes}

As you continue to compare codes, incidences, and categories, you will see how ideas that were initially somewhat descriptive become abstract and conceptual (Glaser, 1978). Keep in mind that "incident tripping" (Glaser, 1998: p. 153), or description with numerous examples, is not the objective of a theory developed using classic grounded theory; such a theory must have "conceptual generality, not unit generality" (Glaser, 
1998: p. 125). In other words, while you are clearly talking about your substantive area, the reader should feel that the information is generalizable to other areas. Let us explore the element of conceptuality from a higher perspective.

After saturation has occurred and a core variable has been found, what is left is to examine your theory from a high level. While your theory represents the main concerns of participants, here we are interested in the relationship of the categories to each other. What is the abstract glue, so to speak, that holds them together? The way categories fit together in relation to each other is via theoretical codes. Though theoretical codes are not required in a classic grounded theory study (Glaser, 2005), they are valuable. According to Glaser $(1978,2005)$, "theoretical codes conceptualize how the substantive codes of a research may relate to each other as hypotheses to be integrated into a theory" (Glaser, 1978: p. 72; Glaser, 2005: p. 2).

In my theory of surviving situational suffering, the three categories are limiting, balancing conflict, and falling short. In the case of this theory, I examined the categories and their properties. How did they all come together? The going back and forth between limiting, balancing, and falling short while progressing through the muck and mire of a part-time adjunct experience allowed me to look carefully at Glaser's (1978, 2005) numerous theoretical codes. I realized that more than one theoretical code was applicable to the theory. On one level, a cause-effect was present (Chametzky, 2015). Full-time educators and administrators did (or did not) do something, which resulted in part-time educators feeling and behaving in a certain way. Additionally, a "conditional relationship" (Chametzky, 2015: para. 7) is present in the theory. The strong interdependence between the categories and situational issues permitted educators to move continuously and in a fluid manner from the beginning to the end of the theory.

I suggest to all novice researchers using classic grounded theory to examine the theoretical codes that Glaser $(1978,2005)$ discussed. Both books helped me develop a certain understanding to conceptual abstraction. Even if you are not yet comfortable with conceptuality, read (or skim) these books; they are invaluable as you learn and experience the classic grounded theory design. As you will undoubtedly see after quickly examining these sources, theoretical codes do not have the same grab as substantive code because theoretical codes "are empty abstractions" (Glaser, 2005: p. 11); they are "models" (Glaser, 2005: p. 12) that are highly useful in a theory developed using classic grounded theory. In Glaser's (1978) work, Theoretical sensitivity, he presented examples of numerous theoretical coding families. If a theoretical family is not applicable to your study-for example, the degree or the concensus families, disregard them. In Glaser's (2005) other book, a great deal of time has been devoted to many other theoretical codes. Glaser (2005) made is very clear that though theoretical codes are valuable and highly useful, they are not a requirement for a classic grounded theory study: "many good GTs have no theoretical code or codes" (p. 59). Do not feel that having theoretical codes in your study is a necessity.

\section{Limitations of This Research}

As beneficial as this research might be to novice grounded theory researchers, it has 
some limitations. Because each research study is unique, it is not possible to explain all the elements in conducting a classic grounded theory study. Though the researcher has explained coding, other aspects of a classic grounded theory design study are missing: interviewing, conducting observations, writing memos, conceptualizing, sorting, and so on. Additionally, there are nuances of substantive and formal theories that have not been addressed here. The scope of this paper, then, is narrow and yet simultaneously points to other elements in classic grounded theory that need to be sufficiently explained. It is hoped that in future publications, the researcher will tackle these other elements of classic grounded theory.

\section{Conclusion}

The process of coding in a classic grounded theory study becomes increasingly difficult as the number of codes, larger patterns of behaviors, and categories increase. Such complexity is normal and should be expected. Coding is not difficult in-and-of-itself; it becomes difficult when we don't constantly compare codes, incidents, categories, and properties. Additionally, if we describe we lose generalizability and fall easily into the realm of too much data. When we conceptualize data, we are able to keep the workload manageable and, more importantly, we decouple data from being tied to places, persons, and time (Glaser, 1998).

\section{References}

Chametzky, B. (2013a). Offsetting the Affective Filter and Online Foreign Language Learners. http://www.igi-global.com/open-access/paper/offsetting-affective-filter-classic-grounded/7

Chametzky, B. (2013b). Generalizability and Offsetting the Affective Filter. Grounded Theory Review, 12. http://groundedtheoryreview.com/

Chametzky, B. (2014). Andragogy and Engagement in Online Learning: Tenets and Solutions. Creative Education, 5, 813-821. http://dx.doi.org/10.4236/ce.2014.510095

Chametzky, B. (2015). Surviving Situational Suffering: A Classic Grounded Theory Study of Post-Secondary Contingent Faculty Members in the United States. Grounded Theory Review, 14, 26.

Gibson, B., \& Hartman, J. (2014). Rediscovering Grounded Theory. London, UK: Sage.

Glaser, B., \& Strauss, A. (1967). The Discovery of Grounded Theory: Strategies for Qualitative Research. Mill Valley, CA: Sociology Press.

Glaser, B. (1978). Theoretical Sensitivity. Mill Valley, CA: Sociology Press.

Glaser, B. (1992). Basics of Grounded Theory Analysis. Mill Valley, CA: Sociology Press.

Glaser, B. (1998). Doing Grounded Theory: Issues and Discussions. Mill Valley, CA: Sociology Press.

Glaser, B. (2001). The Grounded Theory Perspective: Conceptualization Contrasted with Description. Mill Valley, CA: Sociology Press.

Glaser, B. (2005). The Grounded Theory Perspective III: Theoretical Coding. Mill Valley, CA: Sociology Press.

Glaser, B. (2007). All Is [Sic] Data. The Grounded Theory Review, 6, 1-22.

Glaser, B. (2009). Jargonizing Using the Grounded Theory Vocabulary. Mill Valley, CA: Sociolo- 
gy Press.

Holton, J. (2010). The Coding Process and Its Challenges. The Grounded Theory Review, 9, 2140.

Mezirow, J. (1978). Perspective Transformation. Adult Education Quarterly, 28, 100-110. http://dx.doi.org/10.1177/074171367802800202

Spradley, J. (1979). The Ethnographic Interview. NY: Holt, Rinehart and Winston. http://books.google.com/books?hl=en\&lr=\&id=2 Tt3FIm18C\&oi=fnd\&pg=PA44\&dq=spradl ey+\%2B\%22asking+descriptive+questions $\% 22 \&$ ots $=Q$ QNud4eW9IZ\&sig=S1PuRYt3B8IBcLSfa UR8Ov-GXhY\#v=onepage\&q=spradley $\% 20 \% 2 \mathrm{~B} \% 22$ asking $\% 20$ descriptive $\% 20 q u e s t i o n s \% 22 \& \mathrm{f}$ $=$ false

Stern, P., \& Porr, C. (2011). Essentials of Accessible Grounded Theory. Walnut Creek, CA: Left Coast Press.

Submit or recommend next manuscript to SCIRP and we will provide best service for you:

Accepting pre-submission inquiries through Email, Facebook, LinkedIn, Twitter, etc. A wide selection of journals (inclusive of 9 subjects, more than 200 journals)

Providing 24-hour high-quality service

User-friendly online submission system

Fair and swift peer-review system

Efficient typesetting and proofreading procedure

Display of the result of downloads and visits, as well as the number of cited articles

Maximum dissemination of your research work

Submit your manuscript at: http://papersubmission.scirp.org/

Or contact sm@scirp.org 